\title{
What I do, study, and think as an information professional
}

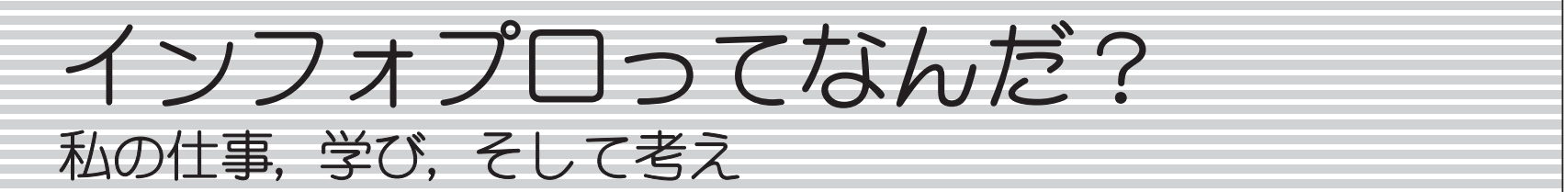

\section{第 27 回松谷 貴己}

日本化薬株式会社 知的財産部

情報管理５4(5), 277-278, doi: 10.1241/johokanri.54.277 (http://dx.doi.org/10.1241/johokanri.54.277)

\section{1.はじめに}

調査業務を担当するようになって随分時間が経過 した。前任者の異動に伴い，研究所の研究企画部門 で調査業務を担当することになってから，数十年に なる。情報や化学の専門知識を持たなかったため， ゼロからのスタートであった。

振り返ると研究所，本社知的財産部の情報担当， 知的財産部情報グループと，同じ調査担当と言って も業務内容は時代の変化もあり随分と变わってきた。

研究所時代は調査をしながら，ドキュメンテーショ ンの基礎に関する文献や化学（農薬），命名法の本や 文献をよく読んだ時代だった。それは，化学および 医農薬という欧米を中心に高度に発達したドキュメ ンテーション技術との出会いの時だった。本社知的 財産部情報担当の時代は調査に分析業務が加わり，

現在よく言われている「Patent Information Analyst」 としてのスタートの時であった。そして現在，情報 グループという組織の運営と調査・分析，図書館運 営を担当し，管理と実務を両立させている。

\section{2. ドキュメンテーションとの出会い}

調査を担当したときに最初に利用したデータベー スはPESTDOC（その後Derwent Crop Protection File， 現在はサービス停止）という，当時英国のDERWENT 社が作成していた農薬分野の会員制データベースで あった。農薬分野の研究では，特許も重要だったが， 同時に文献情報が重要視されていた。PESTDOCには2
つの索引システムがあり，1つはIBMのパンチカード を利用した索引システムで，カードポジションに農 薬の活性成分の化学構造 (部分構造) を表すコード と薬効および製剤等の関連情報の索引があり，化合 物と薬効を効率よく検索することができた。このほ かに、コードレススキャニングという統制語と非統 制語からなるキーワード索引があった。このデータ ベースはこのほかに，抄録には技術分類が付与され， 抄録員の識別もあり，高精度の抄録誌として存在し ていた。高度に加工され当時のドキュメンテーショ ン技術を駆使して作られたもので，用語も名詞と形 容詞，名詞の単数と複数は意味が使い分けられてい る点に驚かされた。これぞヨーロッパのドキュメン テーションとの出会いだった。

農薬分野の特許データベースには，同じく DERWENT社のAGDOC (Chemical Patent Indexのセ クションC）があつた。特許は内容の正確性や必要な 情報の量という面では文献と性格が異なっている。 化学構造の索引はケミカルフラグメンテーション コードを用いてマーカッシュクレームを検索できる ようにしていたため，PESTDOCと比較して索引ルー ルが複雑であった。さらにIPC等の既存の分類に加え てDERWENT社独自のダウエントクラス，マニュアル コードもあり全体には複雑な索引体系であった。特 許という情報の性質上，検索漏れは許されないため， 慎重に検索する必要があった。

この2つの情報源に加えてほぼ同時に使つた資料が 
Chemical Abstracts（以下CA）だった。オンライン 検索が始まったころで，化学物質の新規性の調査を 中心に利用したが，これが化学物質の命名法との出 会いとなった。オンライン検索の習得と同時に印刷 体CAを利用し，Formula Index，Chemical Substance Indexをよく使った。CAという二次資料は1907年か ら存在して膨大な量を誇り，これが米国型のドキュ メンテーションかと思った。

\section{3. 分析業務の始まり}

本社知的財産部に異動になり，調査・分析および 研究部門の調査担当の指導・教育が業務になった。 経営層向けの調査・分析は，主として戦略指示書に 基づき事業戦略に関係するものだった。当時はパテ ントマップの走りのころで電子化されている情報が 少なく，著作権の関係もあり自由に利用できない時 代だった。主にマ二ュアルでパテントマップを作つ ていた。このころは，パテントマップで何ができる かを，社内外の方と意見交換した時代だった。また， マップ化のロジックや情報分析の考え方についての 文献を中心に読んでいた。先のドキュメンテーショ ンとは違い，日本の統計処理や情報分析の手法が参 考になった。ロジックのパラメーターの取り方とそ の意義を考えた。

\section{4. 情報グループの組織化}

専門の異なった研究部門の調査担当を1つの組織に して運営するためには，情報検索のスキルと事業分 野の知識のほか，業界地図，法規制等多くの事業背 景となる情報，知識が必要になるが，知財という組

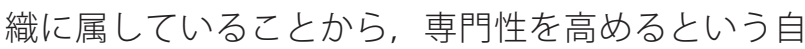
己啓発の環境が整備されていたのはよかったと思う。

社外での研鑽の機会は，特許，化学，医薬等の検索・ 分析・統計処理，図書館等いろいろな業界団体，学 協会，研究会等があり，ある程度（5年位）経験を積 んだ時点で，参加を奨励している。

検索の標準化はある程度までは可能かと思うが，
案件ごとに調査の方法は違っている。ルーチン化で きる調査はエンドユーザーにできる仕事で，情報担 当があえてする必要はなくなつた。また，個々の調 査事例から得られる知識や経験はマニュアルにはな いものが多くある(これに気がつくかどうか)。化学， 医薬等の分野では，専門のデータベースや資料が現 在も多く存在している。これらは概して高額な利用 料金がかかり，利用に当たって高度な知識とスキル が要求される点も大きな特徵である。

\section{5. おわりに}

調査業務を行ううえで情報（検索・分析・加工） スキルを持ち，扱う情報の性質や意味を知っている ことは当然だが，調査の質を上げるうえでは技術分 野の知識が特に重要だと思う。この仕事は，日々変 化する事業環境の中での情報収集が基本になる。必 要と思われる講習会やセミナーには積極的に参加し て，自分の知識を最新のものにする努力をし，わか らないことはその分野の専門家の方のところに足を 運んで教えてもらった。業界団体，学協会の委員， 役員が回ってきたときには，できるだけ引き受ける ようにした。外部活動は個人の負担が大きいが，活 動を通じて社内では得難い経験や財産となるような 人との出会いに恵まれた。国内外の多くの方々と知 り合うことができたことは，のちの仕事にも生かさ れている。

調査担当にとって一番大事なのはユーザーであ る。研究部門にいれば研究者，技術者であり，この 人たちの情報に対する要求，センス，知識が情報担 当を育てる原動力になっている。社内という同じ組 織に属す利害関係の中で，情報の共有と目的意識の 同質性を持って取り組むことが重要である。

経験を積めば積むほど，奥の深さを痛感させられ るのがインフォプロの世界ではないだろうか。「イン フォプロってなんだ」という根源的な問いには，い まだに答えることができずにいる。 